\title{
Towards a nemo judex in parte sua Critique of the International Criminal Court?
}

\author{
Benedict Abrahamson Chigara \\ Professor of International laws, Brunel Law School, Brunel University, \\ London, UK
}

\begin{abstract}
When the relevance or, practice of international tribunals is impugned their tendency often is to resort to 'vivere-existential reflexes'. This habit can incubate conflict between the particular tribunal and the requirements of General Principles of Law recognized by civilized nations. This risks disunity between international law, supranational law and domestic law. This article examines the International Criminal Court's (ICC) application and interpretation of Article 87 of the Rome Statute (1998) under the light of nemo judex in parte sua - a general principle of law recognized by civilized nations. The article recommends that an observatory for monitoring International Tribunals' compliance with general principles of law recognized by civilized nations should be established and a database on non-compliance should be developed and maintained. This should check practice of international tribunals for consistency with general principles of law recognized by civilized nations in a manner that promotes the integrity of international law.
\end{abstract}

\section{Keywords}

general principles of law - nemo judex in parte sua - law's integrity - International Criminal Court (ICC) - law's legitimacy - politico-vivere-reflexes - Article 87 - Rome Statute (1998) 
.... impartiality is the fundamental qualification of a judge and the core attribute of the judiciary. ${ }^{1}$

One of the cornerstones of our legal system is the impartiality of the tribunals by which justice is administered. In civil litigation the guiding principle is that no one may be a judge in his own cause: nemo debet esse judex in propria causa. It is a principle which is applied much more widely than a literal interpretation of the words might suggest. It is not confined to cases where the judge is a party to the proceedings. It is applied also to cases where he has a personal or pecuniary interest in the outcome, however small.

LORD HOPE OF CRAIGHEAD, EX PARTE PINOCHET UGARTE NO.3 [1999]

\section{Introduction}

General principles of law recognized by civilized nations are a seminal source of international law. Article 38(1) of the Statute of the International Court of Justice $^{2}$ (ICJ) prescribes inter alia that the principal judicial organ of the UN the ICJ - whose function is to decide international disputes submitted to it, shall apply norms from the following specific sources:

a. International conventions, whether general or particular, establishing rules expressly recognized by the contesting states.

b. International custom, as evidence of a general practice accepted as Law.

c. The general principles of law recognized by civilized nations.

1 I am indebted to Shalom Malaika Chigara for her assistance and encouragement. Canadian Judicial Council, Ethical Principles for Judges (Canadian Judicial Council, Ottawa, Ontario 1998), p. 30.

2 Statute of the International Court of Justice (1945), 33 UNTS 993. 
Nemo judex in parte sua is an exemplar of general principles of law recognized by most judicial systems of the world. Therefore, its observance by the ICC $^{3}$ should be mandatory. ICC jurisdiction is applicable where States parties that have primary responsibility over the offences are either unable or, unwilling to prosecute them.

The ICC has provoked extremely divergent and even challenging reactions from its Member States parties (MSPs) threatening paralysis of relations between the UN Security Council and the African Union; and also between African States and Western States generally ${ }^{4}$ over exercise of ICC mandate to prosecute individuals alleged to have committed Article 5 crimes under the Rome Statute (1998).

This is rather unfortunate because of the hope that establishment of the ICC had inspired when the Court came into force on 1 July 2002. The operationalization of the ICC has been roundly acclaimed by international constitutionalism $^{5}$ theorists as further strong evidence for the proposition that international institutions are diminishing State power as the basis of international order. Perju writes that, " $[\mathrm{a}] \mathrm{s}$ the locus of political will moves beyond the legal form of the State, constitutionalism becomes the tool of choice for conceptualizing new forms of power and for structuring — and, yes, limiting — the exercise of power' 6

Nonetheless, perceived bias in the emergent implementation of ICC jurisdiction, seemingly in disregard of General Principles of Law recognized by

3 Established by the Rome Statute of the International Criminal Court, (adopted 17 July 1998, entered into force 1 July 2002), 2187 UNTS 90.

4 See also Mandiaye Niang, 'Africa and the Legitimacy of the ICC in Question', 17 International Criminal Law Review (2017) 615-624; Dire Tladi, 'The African Union and the International Criminal Court: The battle for the soul of international law', 34 South African Yearbook of International Law (2009) 57-69; Charles Chernor Jalloh, 'Africa and the International Criminal Court: Collision Course or Cooperation?', 34 North Carolina Central Law Review (2012) 203-229; Jean-Baptiste J. Vilmer, 'The African Union and the International Criminal Court: Counteracting the Crisis', 92 International Affairs (2016) 1319-1342.

5 See especially Jeffrey L. Dunoff, et al. (eds.), Ruling the World? Constitutionalism, International Law and Global Governance (Cambridge University Press, Cambridge, 2009); Armin von Bogdandy, 'Constitutionalism in International Law: Comment on a Proposal from Germany', 47 Harvard International Law Journal (2006) 223-242; Christine E.J. Schwoebel, 'Situating the Debate on Global Constitutionalism', 8 International Journal of Constitutional Law (2010) 611-635; Anne Peters, 'Constitutional Fragments: On the Interaction of Constitutionalization and Fragmentation in International Law', Working Paper No. 2, Centre for Global Constitutionalism, University of St Andrews, http://cgc.wp.st-andrews.ac.uk/files/2015/04/CGC-Working -Paper-No-2-Constitutional-Fragments.pdf, accessed 17 July 2018.

6 Vlad Perju, 'International Constitutionalism and the State: A Reply to Aiofe O'Donoghue', 11 International Journal of Constitutional Law (2013) 1046-1051. 
civilized nations threatens Perju's hope. O'Donoghue has aptly summed up the consequent emergent dilemma thus: 'As long as a State's actions as part of an international constitutional order remain unresolved, the process of constitutionalisation itself cannot be said to be complete or indeed legitimate. ${ }^{7}$ One could say the actions of the Republic of South Africa in the Al Bashir debacle with the ICC (2015) remain legally unresolved, i.e. with no remedy, even after Trial Chamber II's decision of 6 July 2017.

\section{$1.1 \quad$ Background}

On 6 July 2017, Pre-Trial Chamber II of the ICC gave its decision in a matter raised against the Republic of South Africa pursuant to Article 87 of the Rome Statute (1998). This decision was in the context of the outstanding 2009/2010 indictment of President Al Bashir of Sudan allegedly for crimes against humanity, genocide, and war crimes - what du Plessis ${ }^{8}$ calls the holy trinity of crimes.

The Chamber stated that MSPs to the Rome Statute are constrained to execute warrants of arrest issued by the Court and to implement ICC requests for the arrest and surrender of fugitives to the Court. Therefore,

by not arresting Omar Al-Bashir while he was on its territory between 13 and 15 June 2015, the Republic of South Africa had failed to comply with the ICC's request for the arrest and surrender of Omar Al-Bashir contrary to the provisions of the Statute, thereby preventing the Court from exercising its functions and powers under the Statute in connection with the criminal proceedings instituted against Omar Al-Bashir. ${ }^{9}$

\subsection{The Problem}

The decision points to international law's enduring deficit of reliance on State collaboration with international institutions for possible realization of its

7 Aoife O'Donoghue, 'International constitutionalism and the State', 11 International Journal of Constitutional Law (2013) 1021-1045.

8 Max du Plessis, 'The Omar Al-Bashir Case: Exploring Efforts to Resolve the Tension between the African Union and the International Criminal Court', in T. Maluwa, et al. (eds.), The Pursuit of a Brave New World in International Law, (Brill Nijhoff, Leiden, 2017) pp. 431-467, p. 433.

9 The Prosecutor v. Omar Hassan Ahmad Al Bashir, o6 July 2017, ICC, Pre-Trial Chamber II, Decision - Court Room 1, ICC-02/05-01/o9, <www.icc-cpi.int/Transcripts/CR2017_04432 .PDF > accessed 17 July 2018. See also Press release at ICC website 'Al-Bashir case: ICc PreTrial Chamber II decides not to refer the Republic of South Africa's non-cooperation to the ASP or the UNSC' (6 July 2017), www.icccpi.int/legalAidConsultations?name=pri320, accessed 17 July 2018. 
purposes. This conundrum does not and should not absolve the testing of ICC Pre-Trial Chamber II's decision of 6 July 2017 against the Republic of South Africa for consistency with the maxim nemo judex in parte sua - a general principle of international law that prohibits all from adjudicating cases in which they are an interested party. ${ }^{10}$ This is to ensure that justice is not only done, but is seen to be done. ${ }^{11}$

This impartiality test requires disqualification from participation anyone that may give rise even to the slightest apprehension of bias in the proceedings. It is a fundamental principle of natural justice ${ }^{12}$ that belongs in that category of general principles of law recognised by civilised nations -Article 38(1)(c) of the Statute of the International Court of Justice (1946). ${ }^{13}$

The only respondent in the process was the Republic of South Africa. The sole accuser was the ICC itself and not the Assembly of States Parties (ASP), nor the UN Security Council that had triggered the ICC's attention in the matter of crimes allegedly committed by the Sudanese President against his own people in the Darfur region. It would be naïve to argue that it was not the ICC that had brought Article 87 charges against the Republic of South Africa but rather, the Prosecutor of the ICC; and also that it was the Court's duty to hear and consider the pleadings of the Prosecutor, and then to weigh them against any arguments proffered in response by the Republic of South Africa chiefly because there is no institution anywhere under international law of the 'international crimes prosecutor'. Thus, specific prosecution functions had to be established and assigned recently for ad hoc Tribunals for Yugoslavia, Rwanda, Lebanon, Cambodia, etc.

Thus, the dynamic of the ICC established by the Rome Statute (1998) to ensure international criminal justice refers to the activities of the ICC and not to any one part that could not exist outside of the Rome Statute 1998. Gestalt Psychology ${ }^{14}$ is clear that the whole is something else than the sum of its parts. How the Prosecutor of the ICC and the Tribunal operate is authorised by one and the same Statute so much that, to insist that it was not the ICC that had

10 Regina v. Bow Street Metropolitan Stipendiary Magistrate, ex parte Pinochet Ugarte (No 2), 15 Jan 1999, HL [1999] All ER 577.

11 Millar v. Dickson, 24 Jul 2001, PC, [2002] sC 30, p. 63; Rex v. Sussex Justices, ex parte McCarthy [1923] All ER 233, [1924] 1 кв 256, p. 259.

12 See especially Abimbola A. Olowofoyeku, 'Bias in Collegiate Courts', 65(4) International and Comparative Law Quarterly (2016) 895-926; Gabrielle Appleby and Stephene McDonald, 'Pride and Prejudice: A Case for Reform of Judicial Recusal Procedure', 20 Legal Ethics 1(2017) 89-114.

13 Statute of the International Court of Justice (1945) 33 UNTS 993.

14 See also Charlotte Sills et al., An Introduction to Gestalt (Sage Publishing, London, 2012) pp. $45^{-60 .}$ 
charged the Republic of South Africa with non-compliance; or that it was not the ICC that handed down the decision may appropriately be deemed to belong to the realm of fanciful abstraction and intellectual myopia. The sum of it is plain and simple. The Rome Statute's current regime and dynamic for pursuing international criminal justice is what is under observation. It is not the Prosecutor's justice, neither is it the specific trial chamber's justice but only that of the ICc. Could it be said for instance that it was not the England Football Team Captain Harry Kane that scored from the penalty spot against Panama in the recent World Cup tournament held in Russia, but only his left foot that had sunk the ball into the goalkeeper's nets?

The Republic of South Africa was charged with failing to cooperate with the Court to ensure that a fugitive that had landed on its territory was apprehended and surrendered to the ICC. This charge appears to conflict with operation of the basic and general principle of natural justice: nemo judex in parte sua. If this is possibly the case could ICC practice trump this principle without violating international law as the law from nations? How if at all, could any concerns about the Republic of South Africa's alleged non-compliance with the ICC over the $\mathrm{Al}$ Bashir arrest warrants have been addressed without breaching the natural justice strictures entailed in the principle - nemo judex in parte sua?

This article evaluates the process envisioned under Article 87(7) of the Rome Statute (1998) for ensuring MSPs' compliance with the Court's possible requests to arrest and surrender fugitives under the light of the of the nemojudex in parte sua principle..$^{15}$ It tentatively argues that perhaps Pre-Trial Chamber II's decision is defective on account of the nemo judex in parte sua principle. Nonetheless, Trial Chamber II's decision appears inevitable because of Article $87(7)$ of the Rome Statute (1998) - the enabling provision. The Drafters of the Rome Statute (1998) do not appear to have either inscribed or, compensated for the role of the nemojudex in parte sua principle in the logic of Article 87(7).

The unintended consequence of the Drafters' possible omission has played out in the judgment against the Republic of South Africa by Pre-Trial Chamber II. If so, this position could be remedied possibly by revising Article 87(7) of the Rome Statute (1998) so that it inscribes rather than exclude as it presently does, significance of the nemo judex in parte sua principle in all IcC proceedings. The revision would serve to minimise the potential for conflict injected into the ICC dynamic via the current dependence of the ICC on MSPs' cooperation for the enforcement of its arrest warrants.

Amending Article 87(7) seems to be the most straightforward way to correct this problem chiefly because it would otherwise be impracticable to seek to

15 See also Hans Kelsen, The General Theory of Law and State (Russel and Russel, New York, 1945). 
amend a general principle of law recognised by civilized nations only to cater for operational defects in the emergent international criminal justice system. Moreover, general principles of international law recognized by civilized nations regulate other areas of international law, including trade law, marine law, environmental law, etc.

\section{Existential Issues in the Practice of the ICC}

Existential hallucinations might have dimmed ICC Chamber II's wit as often happens when emergent international tribunals' credibility is impugned, particularly in their early years. Huge existential and functional questions have been circling over the ICC in the last ten years, as happened with the ICJ until the Corfu Channel case ${ }^{16}$ arose between the UK and Albania.

\subsection{Lessons from IcJ 'vivere-Existential Reflex' Practice}

In the Corfu Channel case, the ICJ appeared to play the magician's hand with customary international law-making, most probably to justify its four-year inaction with human resources costs to the UN. In a sense, the arrival the Corfu Channel case at the Court was a much welcome distraction from critics who saw it as a white elephant.

However, the Corfu Channel case proved to be less than a blessing for the ICJ's existential questions at the time. Albania, the Respondent party, was not even a member of the UN, and it also had not previously formally recognised the jurisdiction of the ICJ. It also had not ratified the one treaty in international law that the Applicant - the UK - had attempted to mount its case upon for damage to her vessels in Albanian territorial waters while exercising the right of innocent passage.

These circumstances did not caution or hinder a very enthusiastic ICJ from proceeding. For the Court, it probably would have been unthinkable at the time, to make a declaration of non-liquet. ${ }^{17}$ The ICJ proceeded brazenly to disregard custom's secondary rules of recognition ${ }^{18}$ and to straightaway inaugurate a new norm of customary international law on the duty of common

16 Corfu Channel (United Kingdom of Great Britain and Northern Ireland v. Albania), 9 April 1949, International Court of Justice, ICJ Reports 1949, p. 41.

17 A situation where there appears to be no applicable law. See also Neha Jain, 'Judicial Lawmaking and General Principles of Law in International Criminal Law', 57 Harvard International Law Journal (2016) 111-150, p. 114.

18 See also Ben Chigara, Legitimacy Deficit in Custom: A Deconstructionist Critique (Ashgate, Dartmouth, 2001), Chapter 5 . 
humanity to warn others coming into one's territorial waters, of the hazards they might expose themselves to.

Even the applicants, who were then a great naval power, had not in all their pleadings suggested the existence of such a rule of customary international law. In other words, there had been no previous State practice or claims by States to suggest the existence of such a rule under Article $38(1)$ (b) of the Statute of the ICJ.

Nonetheless, and without even the faintest reference to either evidence of State practice or to evidence of opinion juris sive necessitatis that are both required to inaugurate a new norm of customary international law, the ICJ just declared it, and, on that basis, found Albania liable for damage to the British vessels.

In doing so, the ICJ appeared to have indulged itself in 'vivere-existential reflexes'. Ever since that decision of the Court, custom has been tainted with unreliability as a source of law-making in international law. Generations of scholars have problematized custom's legitimacy, with many calling for its denunciation as a viable source of international law. ${ }^{19}$

\subsection{Emergent Icc 'vivere-Existential Reflex' Practice}

Similarly, and for the best part of its existence to date, the ICC has haemorrhaged both the integrity ${ }^{20}$ and the legitimacy ${ }^{21}$ that are required of a judicial

19 See especially Joel P. Trachtman, 'The obsolescence of Customary International Law' (21 October 2014), <ssrn.com/abstract=2512757>, accessed 17 July 2018; Jack L. Goldsmith and Eric A. Posner, 'A Theory of Customary International Law', 66 University of Chicago Law Review (1999) 1113-1178; Patrick J. Kelly, 'The Twilight of CIL', 40 Virginia Journal of International Law (2000) 449-543; Bin Cheng, 'UN Resolutions on outer Space', 5 Indian Journal of International Law (1965) 23-48; Ben Chigara, 'International Tribunal for the Law of the Sea and Customary International Law', 22 Loyola of Los Angeles Comparative and International Law Review (2000) 433-452; Jean Marie Henckaerts, 'Study on customary international humanitarian law: A Contribution to the Understanding and Respect for the Rule of Law in Armed Conflict', 87 International Review of the Red Cross (2005) 175-212; Mario Prost and Paul K. Clark, 'Unity, Diversity \& the Fragmentation of International Law', 5 Chinese Journal of International Law (2006) 341-370; Edward Swaine, 'Rational Custom', 52 Duke Law Journal (2002) 559-627.

20 See Ronald Dworkin, Law's Empire (Fontana Press, London, 1986) pp. 225-54. See also Michael F. Freeman, Lloyd's Introduction to Jurisprudence $\left(9^{\text {th }}\right.$ ed. Sweet and Maxwell, London, 2014) pp. 599-608; D. Robinson, 'The Identity Crisis of International Law', 21 Leiden Journal of International Law (2008) 925-963.

21 See Thomas Franck, The Power of Legitimacy among Nations (oup, Oxford, 1990) pp. 41-9. 
tribunal of any standing. Stuart ${ }^{22}$ has appropriately criticised the Court for amateurism, for a failure to carry out reliable, independent investigations, and for relying on materials provided by the UN, NGOs and other third parties. In the Lubanga case, ${ }^{23}$ the Trial Chamber relied on documents obtained from UN and NGO sources, while accepting that 'persons working for NGOs were the exclusive intermediaries between the Office of the Prosecutor (отр) and the victims and witnesses.'. ${ }^{4}$ This is practice contrary to the nemo judex in parte sua principle.

Stuart's veiled criticisms of ICC's reckless approach to basic criminal law practice strike at the heart of the integrity of the Court's practice. 'Independent investigations by the отР on the ground are still a minor factor or even nonexistent, as in the case in Darfur'. ${ }^{25}$ She also criticises the Court for abusing the confidentiality and non-disclosure provisions in Article 54(3)(e) of the Rome Statute. The отр has a duty under Article $67(2)$ to disclose, as soon as practicable, material in the Prosecutor's possession or control that $\mathrm{s} /$ he believes shows or tends toward strengthening the accused's innocence; that mitigates the accused's guilt; or that may affect the credibility of prosecution evidence. This duty is so mundane among domestic legal systems that it is not necessary to belabour the point here.

Dicker, a self-declared friend of the ICc, has commented on 'self-inflicted' damage to the Court's integrity. Some of the damage emanates from what he correctly describes as the Court's daunting mandate. I will return to this daunting, even ambitious mandate of the ICC project towards the end, and then offer suggestions to support the Court's mission. He writes that:

Challenges the ICc has faced so far include the slow pace of the first and only completed trial; the difficulty of the court making its proceedings relevant in the communities most affected by the crimes thousands of miles from The Hague; flaws in prosecutorial strategy in investigating and selecting cases; and most recently, intense budget pressure from the largest paying states parties. Some of these problems flow from the court's daunting mandate, while others are more self-inflicted. ${ }^{26}$

\footnotetext{
22 Heikelina Verrijn Stuart ,The ICC in Trouble', 6 Journal of International Criminal Justice (2008) 409-417.

23 The Prosecutor v. Lubanga Dyilo, 14 March 2012, ICC, Trial Chamber, 01/04-0106.

24 Verrijn Stuart, supra note 22, p. 409.

25 Ibid., p. 414.

26 Richard Dicker, 'The ICC at 10', 12 Washington University Global Studies Law Review (2013) 539-544, p. 539.
} 
Writing in her personal capacity, Judge and President of the Trial Division at the ICC Joyce Aluoch ${ }^{27}$ laments inter alia, serious ICC challenges with ensuring the fair treatment of accused persons. She laments too the ICC's capacity to achieve expeditious prosecutions. Language difficulties are an issue at the ICc. They severely exercised Trial Chamber IV in Prosecutor v. Banda and Jerbo, ${ }^{28}$ and seriously hindered a fair and expeditious hearing of the case, particularly because each of the accused only understood one language - Zaghawa. Zaghawa 'is not a written language... . [Its] vocabulary is limited to no more than 5,000 words, rendering it difficult to translate certain words and concepts from languages of the Court such as English, French and Arabic into Zaghawa. ${ }^{29}$

Consequently, the material that needed to be translated and disclosed reached around 3,700 pages. ${ }^{30}$ This challenge took the Court into the realms of 'creative problem solving' in order to ensure that the trial followed the practice directions set in the Rome Statute. ${ }^{31}$ But procedural creativity is discretionary and risks inconsistency and arbitrariness - the very antipathies of justice. In particular, they raise challenges around the equal treatment of accused persons under the Rome Statute, even for the same offence. ${ }^{32}$ Jain argues that $j u$ dicial creativity by international criminal courts is deeply problematic, fitful, contradictory, and often misguided. It has the potential to 'fail to comply with the principle of legality in criminal law, especially the requirements of fairness and notice to the accused' ${ }^{33}$

Serious strategic shortcomings for a court mandated to prosecute often powerful and versatile persons in terms of their protection from arrest in their native zones of operation include the Court's dependence on MSPs to act as its

27 Joyce Aluoch, 'Ten years of trial proceedings at the International Criminal Court', 12 Washington University Global Studies Law Review (2013) 433-450.

28 Prosecutor v. Banda and Jerbo, Judgment of 17 February 2012, ICC, 02/05-03/o9-214.

29 Aluoch, supra note 27, p. 436.

3 Ibid.

31 Ibid., p. 437.

32 Emphasising the role of Article $38(1)$ (c) premised discretion in the production of judgments, see especially Christopher A. Ford, 'Judicial Discretion in International Jurisprudence: Article 38(1)(c) and General Principles of Law', 5 Duke Journal of International and Comparative Law (1994) 35-86. Advocating judicial discretion to fill gaps in international criminal law, see Shane Darcy and Joseph Powderly (eds.), Judicial Creativity at the International Criminal Tribunals (oup, Oxford, 2010). See also 'Dworkin and Discretion', in Michael F. Freeman, Lloyd's Introduction to Jurisprudence $\left(9^{\text {th }}\right.$ ed. Sweet and Maxwell, London, 2014) pp. 596-7.

33 Jain, supra note 17, p. 112. 
primary compliance arm. '[T] he Court lacks any direct power to carry out the arrests of those people indicted for crimes within its jurisdiction.' ${ }^{34}$

Current State practice shows that the hopes of the Draftsmen of the Rome Statute (1998) that States would facilitate the arrest and surrender of accused persons has proved illusory. In fact, this has proved to be the fundamental fault line in the strategic architecture of the ICC project. Even worse, attempts by the Court to foist that compliance by implementing Article 87(7) have created enormous difficulties all-round. For the ICC project to remain on track and possibly succeed, its strategy for apprehending fugitives requires a radical rethink and re-formulation.

With all these and other challenges and criticisms, ${ }^{35}$ it is not surprising that some of the ICC's recent practices can only be described as vivere-existential reflexes. For instance, the ICC's disregard of nemo judex in parte sua, evidenced in the charges of non-compliance against Chad and Malawi (2011), ${ }^{36}$ and more recently against the Republic of South Africa (2017), is incomprehensible.

Moreover, the ICC has been accused of focusing on and targeting African States because of their weak regional standing in world affairs. It has also been criticised for projecting Africans as if they dominated the inhumanity that underlies Article 5 crimes that the Court is mandated to prosecute. ${ }^{37}$ Human Rights Watch Director Kenneth Roth writes that:

Some of the ICC's problems are of its own making. The Chief Prosecutor for its first nine years, Luis Moreno Ocampo of Argentina, seemed more interested in issuing arrest warrants than undertaking the tough, less glamorous work of conducting rigorous criminal investigations. So far six of the thirty-one prosecutions he launched—three in Kenya, two in Congo, and one in Sudan - have been withdrawn, dismissed, or led to acquittal due to lack of evidence. ${ }^{38}$

34 Matthew Gillet, 'Fighting Impunity: Assisted Arrests at the ICC', 3 Yale Journal of International Affairs (2008) 16-32.

35 See also Malick N. Mandiaye, 'Africa and the Legitimacy of the ICC in Question', 17 International Criminal Law Review (2017) 615-624; Courtney Hillebrecht and Scott Straus, 'Who Pursues the Perpetrators: State Cooperation with the ICC', 39 Human Rights Quarterly (2017) 162-188.

36 International Legal Materials Vol. 51, No. 2 (2012), pp. 393-417; ICC-02/05-01/09-302 o6-07-2017 53/53 Rн Рт.

37 Kenneth Roth, 'Africa Attacks the ICC', (14 January 2014) Human Rights Watch, https:// www.hrw.org/news/2014/01/14/africa-attacks-international-criminal-court, accessed 17 July 2018.

$38 \quad$ Ibid. 
In 2009, and again in 2010, ICC arrest warrants were issued against Sudanese President Al Bashir alleging war crimes, crimes against humanity, and genocide allegedly committed in the Darfur region. ${ }^{39}$ The African Union has routinely criticized these arrest warrants and denounced the UN Security Council for its role in this development. ${ }^{40}$

In spite of Article 86 obligations upon MsPs of the Rome Statue to 'cooperate fully with the Court in its investigation and prosecution of crimes within the jurisdiction of the Court', African States have preferred to comply instead with AU Resolutions that require them not to comply with ICC and UN Security Council mandates for the arrest and surrender of President Al Bashir. This has been adduced as evidence of an emerging $A U$ supranational constitutional customary international law. ${ }^{41}$ Could this counter-ICC African regional State practice be superior to international law?

\subsection{ICc 'vivere-Existential Reflex' Practice v. AU Supranational Laws}

The only parallel to emergent $A U$ supranational constitutional customary international law is supranational European Union Law. The Court of Justice of the European Union's (CJEU) 2008 decision in the Kadi cases ${ }^{42}$ that deliberately challenged UN Security Council orders to freeze assets of persons suspected of funding international terrorism is instructive. The CJEU insisted that unless such orders comply with the requirements of the rule-of-law, they shall be treated as null and void in the EU. In paragraph 378 of its judgment, the Court concluded that, 'Mr Kadi and Al Barakaat's appeals must be upheld and ... the contested regulation must be annulled in so far as it concerns the appellants...'

Since the promulgation of the 2009 and 2010 arrest warrants against President Al Bashir, several African States have hosted President Al Bashir and declined to cooperate with contemporaneous ICC requests for his arrest and surrender to the Court. They include Chad, Kenya, Djibouti, Malawi and more

39 Theorising Rome Statute Article 5 crimes, see especially David Luban, 'A Theory of Crimes Against Humanity', 29 Yale Journal of International Law (2004) 85-167.

$40 \quad$ See du Plessis, supra note 8, p. 440.

41 Ben Chigara, 'The administration of International Law in National Courts and the Legitimacy of International Law', 17 International Criminal Law Review (2017) 909-934.

42 Joined Cases C-402/05 P and c-415/05 P Yassin Abdullah Kadi and Al Barakaat International Foundation v. Council of the European Union and Commission of the European Communities, Grand Chamber decision of 2008, ECJ, <http://eur-lex.europa.eu/legal-content/EN/ TXT/HTML/?uri=CELEX:62005CJ0402\&from=EN > accessed 17 July 2018. 
recently the Republic of South Africa. ${ }^{43}$ It has become almost a badge of honour among African States to host President Al Bashir of Sudan and to scoff at corresponding ICC requests for his arrest and surrender.

The ICC strategy of referring non-complying African States to the UN Security Council for failure to turn-in President Al Bashir has achieved no significant result either. In fact, it appears to have emboldened AU defiance of the Court, leading to the recent Pre-Trial Chamber II's decision against the Republic of South Africa on 6 July 2017. Surprisingly the decision did not include a referral to the UN Security Council for South Africa's declared noncompliance. For its own part, the UN Security Council appears to be unwilling to take any action after a declaration of non-compliance - Chad and Malawi being examples.

The 'realism' of the Un Security Council to take no action after Pre-Trial Chamber I's referral of Chad and Malawi for failure to comply with the Court's requests; ${ }^{44}$ and of Pre-Trial Chamber II's shying away from referring the Republic of South Africa to the UN Security Council ${ }^{45}$ probably points to a recognition in both cases of what might be presently feasible in international criminal law and what may still be premature.

Secondly, it points to a legitimacy defeating fault-line in the crafting of the Court's enforcement mechanisms in light of international law's dependence on States for the enforcement of its terms. Legitimacy ${ }^{46}$ refers also to an institution's pull of its addressees towards voluntary compliance.

Thirdly, it points to the current underdevelopment of international law generally. It appears premature to even expect international law to ensure international criminal justice without the consent of States.

Each ICC judicial decision immediately begs the question of enforcement. The linking of judicial findings ${ }^{47}$ to un Executive action is problematic because

43 See also Alexander K.A. Greenwalt, 'Introductory Note to the ICc: Decisions Pursuant to Article 87(7) of the Rome Statute on the Failure by the Republic of Malawi and the Republic of Chad to Comply with the Cooperation Requests Issued by the Court with Respect to the Arrest and Surrender of Omar Hassan Ahmad Al Bashir and African Union Response', 51 International Legal Materials (2012) 393-417.

44 See ICC-02/05-01/o9-140-tENG 23-03-2012 1/9 NM PT, paras. 13 and 14.

45 See ICC-02/05-01/09-302 06-07-2017 53/53 RH PT, para. 140.

46 Thomas M. Franck, The Power of Legitimacy Among Nations (ou P, Oxford, 1990) p. 38.

47 See also Martha Minow, et al. The First Global Prosecutor: Promise and Constraints (Law, Meaning, and Violence) (University of Michigan Press, Michigan, 2015); Hirad Abtahi and Steven A. Koh, 'The Emerging Enforcement Practice of the International Criminal Court', 45 Cornell International Law Journal (2012) 1-23. 
of its discretionary nature. Pre-Trial Chamber I referred Chad and Malawi for possible UN Security Council action while Pre-Trial Chamber II did not refer the Republic of South Africa in spite of similar findings.

It points to a very weak mechanism for the enforcement of ICC decisions. It is an unsustainable link to the extent that it renders sterile any ICC findings or declarations of non-compliance if the UN Security Council does nothing about them, as long as the defiant MSPs maintain their 'recalcitrant' conduct.

This link is concerning also because the UN Security Council exercises only political executive authority while the ICC and other international tribunals exercise only judicial authority. Political and judicial competences at the moment are conflated when the ICC refers to the UN Security Council MSPs for non-cooperation with their obligations under Articles 86 and 87 of the Rome Statute (1998). This is problematic. It might be a factor contributing to non-cooperation with ICC requests, particularly among those groups of States that have been calling for democratization and reform of the UN Security Council to reflect what they themselves perceive as the new world order. ${ }^{48}$

Among African States, receiving ICC declarations of non-compliance with requests for cooperation appear to have become a prized solidarity symbol against the nagging kicks of perceived neo-imperialism in the continent's affairs. One tentative solution to this might be to develop a list of powers that can be applied against a MSP found to have failed the 'obligation to cooperate with ICC test'. Of course, the question of who decides the prior question of fact is still a very important question not least because of the lingering requirements imposed by the nemo judex in parte sua principle qua customary international law.

Modest fines and a decency ranking chart that is reviewed periodically with States going up or down the scale depending on their practice are possible options. Other international institutions might begin to refer to such a decency ranking chart when considering possible dealings with other States, thereby incentivising greater decency among ICC MSPs in their handling of cooperation requests in the long run.

48 See especially Sahar Okhovat, “The United Nations Security Council: Its Veto Power and Its Reform', CPACS Working Paper No. 15/1, University of Sydney (December 2011), <sydney. edu.au/arts/peace_conflict/docs/working_papers/UNSC_paper.pdf $>$, accessed 17 July 2018. 


\subsection{Intensifying AU Supranationalism v. International Executive Authority of the UN Security Council}

Following Pre-Trial Chamber I's declaration of non-compliance against Chad and Malawi ${ }^{49}$ the $\mathrm{AU}$ Commission expressed its total disagreement with the decisions of the Pre-Trial Chamber I and declared on 9 January 2012 that the earlier AU Assembly Declarations on non-cooperation with UN Security Council and ICC arrest warrants against President Al Bashir remained binding on AU member States parties. ${ }^{50} \mathrm{~A}$ month later, the AU Assembly issued a Declaration reminding African States of their obligation under AU Law, not to comply with any future requests of the ICC and mandated the AU Commission to 'consider seeking an Advisory Opinion from the International Court of Justice regarding the immunities of State Officials under international law'.51

The Republic of South Africa's ruling African National Congress reacted to the interim prohibitive travel order ${ }^{52}$ against $\mathrm{Al}$ Bashir issued by the North Guateng Division of the High Court of the Republic of South Africa with the statement that the ICC had lost its relevance. ${ }^{53}$ President Jacob Zuma is on record for emphasizing that there is an unequivocal AU position on the ICC and that '... the United Nations Security Council should have listened to Africa before issuing the interdict' against President Al Bashir of Sudan. ${ }^{54}$ Perhaps by not acting upon the Chad and Malawi referrals of the ICC upon its finding that the two had each failed the Article 87(7) compliance test, the UN Security Council has now begun to listen to the AU policy on the ICC.

This African position is also evident in the outcomes of the lex specialis 'AU Extraordinary Summit on Africa-ICc Relationship' held on 12 October 2013 by

49 The Prosecutor v. Omar Al Bashir, 19 October 2011, ICC, Pre-Trial Chamber I, 02/05-01/og, <http://www.worldcourts.com/icc/eng/decisions/2011.10.19_Prosecutor_v_Al_Bashir .pdf>, accessed 17 July 2018; Greenwalt, supra note 43, p. 397.

5o Ibid., p. 393 .

51 Ibid.

$5^{2}$ Southern Africa Litigation Centre v. the Minister of Justice and Constitutional Development $\& 9$ Others, North Gauteng HC, Pretoria, Case No. 27740/15.

53 See also Owen Bowcott and Jamie Grierson, 'Sudan's President barred from leaving South Africa', The Guardian, 15 June 2015, www.theguardian.com/world/2015/jun/14/sudan -president-omar-al-bashir-south-africa-icc, accessed 17 July 2018.

54 Bathandwa Mbola, 'Au leaders will not extradite Al Bashir' South African Government News Agency (6 July 2009), <www.sanews.gov.za/south-africa/au-leaders-will-not-extra dite-al-bashir $>$, accessed 17 July 2018. 
the highest decision-making organ of the $\mathrm{AU}$ - the Assembly. ${ }^{55}$ It decided inter alia:

1) That no International Court or Tribunal has capacity to commence or to continue charges against any serving AU Head of State or Government or anybody acting or entitled to act in such capacity during their term of office.

2) To fast track the establishment of the criminal jurisdiction of the African Court on Human and Peoples' Rights and to table for discussion at the Assembly of State Parties of the ICC, amendments to the ICC on immunity of heads of state and government among other matters. ${ }^{56}$

The AU position is apparent from State practice which clearly follows AU supranational directives and trumps ICC and UN Security Council orders. Chad hosted President Al Bashir in July 2010 at a summit of the Sahel Saharan States held in N'Djamena, thereby becoming the first State Party to the Rome Statute to harbour 'knowingly and willingly a fugitive...wanted by the Court' and attracting severe criticism from NGOs and observers. ${ }^{57}$

The abjuration was based on the assumption that Chad, as a State Party to the Rome Statute, would arrest, detain and facilitate transfer formalities to The Hague, any person of interest to the ICC. Subsequently, President Al Bashir was hosted on two occasions in 2010, by the Republic of Kenya - another State Party to the Rome Statute -, as a guest of the Kenyan government during the August celebrations that marked the occasion of Kenya's new Constitution. He was hosted a second time as a participant to a summit for the InterGovernmental Authority for Development (IGAD) held in Nairobi in October 2010 to discuss the forthcoming referendum for the secession of Southern Sudan from Sudan.

At a meeting which took place in New York in the aftermath of President Al Bashir's visit to Kenya, between the President of the ICC Assembly of State

55 AU Extraordinary Summit on Africa-ICc Relationship, Ext/Assembly/AU/Dec.1(Oct.2013); see also S.A. Dersso, 'The AU's Extraordinary Summit decisions on Africa-ICC Relationship' EJIL: Talk (2013), www.ejiltalk.org/the-aus-extraordinary-summit-decisions-on-africa-icc -relationship/, accessed 17 July 2018.

56 AU Extraordinary Summit on Africa-Icc Relationship, Ext/Assembly/AU/Dec.1 (Oct. 2013).

57 Johan David van der Vyer, 'Prosecuting the President of Sudan: A dispute between the African Union and the International Court', 11 African Human Rights Law Journal (2011) $683-698$, p. 686. 
Parties (ASP), Ambassador Christian Wenaweser of Liechtenstein, and the Kenyan Minister of Foreign Affairs; Kenya explained that it had refused to execute the arrest warrant because it believed that it had 'competing obligations toward the Court, the $A U$, and regional peace and stability'. ${ }^{8}$ Du Plessis' argument on this point is inconsistent with the enablence object and purpose test of diplomatic relations declared by the ICJ in the Case Concerning the Arrest Warrant of 11 April 2000 (DRC v. Belgium). ${ }^{59}$

Du Plessis begins his argumentation very well. '... let us assume that the Al-Bashir saga exemplifies a fight for the soul of international criminal law' which it does. He proceeds:

... The responsible thing for the Republic of South Africa to have done was to avoid the conflict all together. The Republic of South Africa could have done this by not allowing its territory to be used for purposes of Bashir's visit- either by declining to host the meeting when it knew that Bashir was intent on visiting under encouragement of the $\mathrm{AU}$, or by warning Bashir that he may well face possible arrest if he insisted on coming. But that didn't happen, and history has now been written. ${ }^{60}$

According to this argument, the Republic of South Africa should abandon her responsibility to foster international relations with the AU and within its region. Short of that it should constrain its diplomatic function internally and externally. But for what benefit? The ICJ stated in the Arrest Warrant Case that international law is there to enhance States' diplomatic relations with other States, and not to constrain them. That is one of international law's foremost functions. It is repeatedly rehearsed in cardinal international agreements, including the UN Charter, ${ }^{61}$ the UN Declaration on Principles of international law Concerning Friendly Relations and Co-operation among States, ${ }^{62}$ etc. The ICJ stated:

$5^{8}$ ICC Press Release of 21 September 2010, 'President of the Assembly of States Parties meets Minister of Foreign Affairs of Kenya' Doc ICC-ASP-20100921-PR575 (emphasis added).

59 Case Concerning the Arrest Warrant of 11 April 2000 (DRC v. Belgium), Judgment of 14 February 2002, International Court of Justice, I.C.J. Reports 2002, p. 3.

6o Du Plessis, supra note 8, p. 437 (emphasis added).

61 Charter of the United Nations (1945) 1 UNTS XVI.

62 UN Declaration on Principles of International Law Concerning Friendly Relations and Cooperation among States (24 October 1970) UN General Assembly Resolution 2525, UN Doc. A/RES/25/2625. 
As in the case of the warrant's issue, its international circulation from June 2000 by the Belgian authorities, given its nature and purpose, effectively infringed Mr. Yerodia's immunity as the Congo's incumbent Minister for Foreign Affairs and was furthermore liable to affect the Congo's conduct of its international relations. Since: Mr. Yerodia was called upon in that capacity to undertake travel in the performance of his duties, the mere international circulation of the warrant, even in the absence of 'further steps' by Belgium, could have resulted, in particular, in his arrest while abroad. .... Accordingly, the Court concludes that the circulation of the warrant, whether or not it significantly interfered with Mr. Yerodia's diplomatic activity, constituted a violation of an obligation of Belgium towards the Congo, in that it failed to respect the immunity of the incumbent Minister for Foreign Affairs of the Congo and, more particularly, infringed the immunity from criminal jurisdiction and the inviolability then enjoyed by him under international law. ${ }^{63}$

It is clear that international law's function is to maximise capacity for interState engagement rather than to minimise, hinder or dwindle it. Antagonizing the regional body and minimizing the Republic of South Africa's relations in the world is the legacy of apartheid South Africa's regimes. This is not to be encouraged in the post-apartheid era, no matter how used to that approach others may be.

In the face of unparalleled hostile defiance by a group of States that had most helped the Rome Statute achieve the 6o ratifications required to bring it into force, the ICC must definitely be reaching for its own pulse for life. No other international judicial tribunal has suffered this level of existential threat, especially in its embryonic phase.

ICC non-compliance problems are not dissociated from what is now visibly showing as the poor drafting of the Rome Statute (1998). The current non-cooperation challenges have forced these drafting deficiencies to the surface. In particular, the drafters failed to inscribe into the procedural dynamic of the Court, the nemo judex in parte sua principle, itself a General Principle of Law recognized by civilized nations - Article 38(1)(c) of the Statute of the ICJ.

63 Case Concerning the Arrest Warrant of 11 April 2000 (DRC v. Belgium), Judgment of 14 February 2002, International Court of Justice, I.C.J. Reports 2002, para. 71 (emphasis added). 
3 Basic Principles of law recognized by civilized nations: Article 38(1) (c) Statute of the International Court of Justice (ICJ) ${ }^{64}$

Although Article 1 of the Statute of the ICJ (1945) is specific to the ICJ itself, it has evolved into customary international law on the sources of international law that govern the practice of international tribunals. ${ }^{65}$

Although treaties and customary international law have dominated discourse on sources for a while now, Schlesinger writes that the 'general principles' referred to in sub-paragraph (c) of the Statute of the ICJ 'are a primary source, [and] often the only source of international law in the absence of an applicable treaty'66 And even where a treaty could apply, its interpretation may depend upon resort to the General Principles of Law recognized by civilized nations. ${ }^{67}$ Cherif Bassiouni writes that, going forward General Principles of Law recognized by civilised nations will likely become the seminal source of international law because:

As the world's interdependence increases, there will doubtless be greater reliance on international law as a means to resolve a variety of issues which neither conventional nor customary international law is ready to meet. The fast pace of human rights will also bring to the forefront of international, regional, and national adjudication issues which heretofore may have only been viewed as theoretical. The four most pressing issues that will advance to the forefront ... are: human rights, the environment, economic development, and international and transnational criminality. Even the casual observer will note that in these four areas, conventional and customary international law have not developed the framework, norms, or rules necessary to regulate these issues, nor is it likely that these two sources of law will catch up with the needs of the time. Thus,

64 See especially R.B. Schlesinger, 'Research on the General Principles of Law Recognized by Civilized Nations', $5_{1}$ American Journal of International Law (1957) 734-753; F.T.F. Jalet, 'The Quest for the General Principles of Law Recognized by Civilized Nations - A Study', 10 University of California Los Angeles Law Review (1963) 1042-1086; Christopher A. Ford, 'Judicial Discretion in International jurisprudence: Article 38(1)(c) and General Principles of Law', 5 Duke Journal of International and Comparative Law (1994) 35-86; Jain, supra note 17, pp. 111-150; M. Cherif Bassiouni, 'A Functional Approach to General Principles of International Law', 11 Michigan Journal of International Law (1989-1990) 768-818.

65 James Crawford, Brownlie's Principles of International Law (ed. $8^{\text {th }}$ ed. oup, Oxford, 2012) p. 23. See also Schlesinger, supra note 64, p. 734.

66 Schlesinger, ibid. p. 735 .

67 Ibid. 
it is quite likely that 'General Principles' will become the most important and influential source of international law ... Existing needs and conflicts will necessarily require some legal basis for their satisfaction and resolution. In this case, the definition, identification, and functional use of 'General Principles, will require more rigorous attention than has thus far been given to these questions. For the same reasons, greater rigor will be demanded of the rather loose manner in which jus cogens has been defined, identified, and applied by various writers. ${ }^{68}$

General principles of law derive from a common expression of national legal systems. ${ }^{69}$ They have been defined invariably as those 'cardinal principles of the legal system, in the light of which international law is to be interpreted and applied'; and also as 'obvious maxims of jurisprudence of a general and fundamental character'.70 Yet others have characterised them as being the equivalent of an international common law sprouting out of the core concepts, norms and rules of national legal systems. ${ }^{71}$ They are 'foundational ordering norms in a global, interdependent community.' ${ }^{72}$

These principles are immutable because they derive from, and are the commonest principles emanating from municipal legal systems of nation States. According to Jalet, they are '... foundational and underlie all legal systems, for there should be no divergence - they are everywhere the same. ... They are law in both the national and international spheres, and it is these principles to which Article $38(1)$ (c) refers to. ${ }^{73}$ Schlesinger perceives them as the general standards of legal and judicial decency that 'civilized nations recognize in their municipal legal systems, and sometimes in collective declarations.' ${ }^{74}$

They take the form of substantive standards as well as procedural and evidentiary principles which are felt to be inherent in all civilized legal systems.

68 Cherif Bassiouni, supra note 64 , pp. $768-818$, p. 769 . Discussing the increasing significance to dispute resolution in the wTo dispute settlement system, see also Maria Panezi, 'Sources of Law in Transition Re-visiting General Principles of International Law', (2007) ANCILIA JURIS at Researchgate, <www.researchgate.net/publica tion/26495501_Sources_of_Law_in_Transition_-_Re-visiting_General_Principles_of_Inter national_Law>, accessed 17 July 2018.

$69 \quad$ Ibid., p. 768.

$70 \quad$ Ibid., p. 770.

$71 \quad$ Ibid., p. $77^{2}$.

72 Ibid., p. 773 .

73 Jalet, supra note 64, pp. 1075-1076.

74 Schlesinger, supra note 64, p. 736. 
It is the generality of their application that determines their status as a general principle and not the generality of the legal idea underlying it. ${ }^{75}$ Bassiouni concludes that: 'if a principle exists in most national laws, it is likewise inherently part of the structure of international law, which can best regulate the conduct of States by applying those principles which are recognized by these States.7 ${ }^{76}$ Equity, Fairness, Proportionality, and Human Rights are good examples of common expressions of all national legal systems. ${ }^{77}$

Cherif Bassiouni provides a non-exhaustive list of possible functions of general principles of law in the international legal system. ${ }^{78}$ This writer would add to that list, the assurance of integrity and legitimacy to the sphere of law under consideration, especially by upholding the requirement of natural justice.

Across both civil law and common law jurisdictions, the doctrine of natural justice is applied to monitor and to critique law for fairness of its standards and procedures; and for its consistency with requirements of the principle of the rule-of-law. ${ }^{79}$ According to The Secretary General of the UN, the rule-of-law is:

... a principle of governance in which all persons, institutions and entities, public and private, including the State itself, are accountable to laws that are publicly promulgated, equally enforced and independently adjudicated, and which are consistent with international human rights norms and standards. It requires, as well, measures to ensure adherence to the principles of supremacy of law, equality before the law, accountability to the law, fairness in the application of the law, separation of powers, participation in decision-making, legal certainty, avoidance of arbitrariness and procedural and legal transparency. ${ }^{80}$

Under English law, natural justice refers to the general duty to act fairly. Fairness is ensured by two doctrines, namely, the rule against bias - nemo judex in parte sua; and the right to a fair hearing - audi alteram partem.

75 Jalet, supra note 64, p. 1046.

76 Cherif Bassiouni, supra note 64, p. 773.

77 See also Jalet, supra note 64, pp. 1044-50.

78 Cherif Bassiouni, supra note 64, pp. 775-6.

79 See also Tom Bingham, The Rule of Law (Penguin, London, 2011).

80 United Nations and the Rule of Law, 'What is the Rule of Law', <https://www.un.org/ ruleoflaw/what-is-the-rule-of-law/>, (emphasis added), accessed 17 July 2018. 
In Pinochet No. ${ }_{2}{ }^{81}$ the U K Supreme Court - House of Lords as it then was ruled that the relationship between Amnesty International and Lord Hoffmann automatically disqualified him from hearing the case. Therefore, an earlier judgment could not stand. This was because Amnesty International had been granted leave to act as interveners in the case. After judgment was announced new disclosures showed that one of the five judges - Lord Hoffman - was an unpaid director and chairperson of Amnesty International Charity Limited and that his wife was employed by Amnesty International.

This led General Pinochet to challenge the Court's finding on the grounds that Lord Hoffmann should have declared his connections to Amnesty International because those links were sufficient to give rise to the appearance of possible bias. The possibility of bias, and not the proof of it, was sufficient to cast doubt on the integrity of earlier proceedings. The matter of the Spanish Magistrate's application for extradition of Senator Pinochet Ugarte to Spain to answer charges of universal jurisdiction offences allegedly committed while head of the State of Chile had to be reheard in open court, all over again. This is how significant the nemo judex in parte sua principle is in practice.

Malleson ${ }^{82}$ has criticised the judgment for attacking the integrity of very senior judges. This writer does not share that view. The judgment appears to prudently inscribe rather than exclude, as Malleson's suggestion might, the General Principle of Law recognized by civilized nations - itself a cardinal requirement of natural justice, namely, that justice must not only be done, but must be seen to be done. This is a well-established and ancient requirement of Administrative Law wherever one looks.

In Rex v. Sussex Justices, ex parte McCarthy, D had been prosecuted for dangerous driving. Unknown to the defendant and his solicitors, the Clerk to the Justices was a member of the firm of solicitors acting in a civil claim against D. The claim had arisen out of the accident that had given rise to D's prosecution. The Clerk retired with the Justices, who returned to convict D as charged. On learning of the Clerk's provenance, $\mathrm{D}$ applied to have the conviction quashed. The Justices swore affidavits stating that they had reached their decision to convict D without the involvement of their Clerk.

81 Regina v. Bow Street Metropolitan Stipendiary Magistrate, ex parte Pinochet Ugarte (No 2), 15 Jan 1999, HL, [1999] All ER 577.

82 Kate Malleson, 'Judicial Bias and Disqualification after Pinochet No.2', 63(1) Modern Law Review (2000) 119-127. See also <https://onlinelibrary.wiley.com/toc/14682230/2000 $/ 63 / 1>$. 


\section{Per Lord Hewart cJ:}

It is said, and, no doubt, truly, that when that gentleman retired in the usual way with the justices, taking with him the notes of the evidence in case the justices might desire to consult him, the justices came to a conclusion without consulting him, and that he scrupulously abstained from referring to the case in any way. But while that is so, a long line of cases shows that it is not merely of some importance but is of fundamental importance that justice should not only be done, but should manifestly and undoubtedly be seen to be done. The question therefore is not whether in this case the deputy clerk made any observation or offered any criticism which he might not properly have made or offered; the question is whether he was so related to the case in its civil aspect as to be unfit to act as clerk to the justices in the criminal matter. The answer to that question depends not upon what actually was done but upon what might appear to be done. Nothing is to be done which creates even a suspicion that there has been an improper interference with the course of justice. Speaking for myself, I accept the statements contained in the justices' affidavit, but they show very clearly that the deputy clerk was connected with the case in a capacity which made it right that he should scrupulously abstain from referring to the matter in any way, although he retired with the justices; in other words, his one position was such that he could not, if he had been required to do so, discharge the duties which his other position involved. His twofold position was a manifest contradiction. In those circumstances, I am satisfied that this conviction must be quashed, unless it can be shown that the applicant or his solicitor was aware of the point that might be taken, refrained from taking it, and took his chance of an acquittal on the facts, and then, on a conviction being recorded, decided to take the point. On the facts, I am satisfied that there has been no waiver of the irregularity, and, that being so, the rule must be made absolute and the conviction quashed. ${ }^{83}$

Integrity of the law deserves a higher priority than presumed human integrity, no matter how esteemed the humans in question may be. The two should never be confused or, conflated. On the contrary, one should always be mindful of the distinction. While the law's integrity rests on its own evolution and development through interpretive reasoning that is refined over time to arrive at

83 Rex v. Sussex Justices, ex parte McCarthy [1923] All ER 233, [1924] 1 кв 256 (emphasis added). 
cogent principles that inspire objective confidence in their dictates; judges as humans are mere mortals whose inclinations, no matter how outstanding they might be, can never be compared under the same light to law's independent and separable integrity.

For instance, a judge may fall from grace and never again be allowed to practice law. However, any decisions s/he may have handed down will not fall with her/him; neither would any persons he might have sentenced to lengthy prison terms be released because $s /$ he has fallen from grace. His/her seminal judgments would continue to influence the course of justice because they belong to law's interpretive logic, and not to the judge herself/himself for they were only a servant of the process to progress law and justice's purposes.

Judges are dependent on law's integrity for the public appropriation of their own judgments. The law does not and cannot depend on their perceived integrity for its own integrity. Neither does the law depend on judges' personal integrity to be valid. It is not a case of 'this is a good judgment because it was made by the venerable Judge X.' For this reason, judges have to justify their rulings with legal reasoning that can be tested and challenged by others, including their peers, for consistency with the valid laws of the legal environment that they are operating in.

Moreover, the correct interpretation of the basis of the bias test is that it is not the integrity of the judge(s) that is at issue, but rather, the independent perception of an onlooker, and what s/he would conclude would happen if the circumstances of the judges were made known to her/him.

The prohibition against bias is a fundamental requirement of administrative law and human rights law. It is critical to justice so that even the mere suspicion of bias or, the mere apprehension of it is sufficient to require the setting aside of the affected judgment(s). In other words, judgments are immediately corrupted and deemed as invalid by the mere apprehension of bias, and not the proof of it. This threshold is much, much lower than the criminal law culpability test of beyond reasonable doubt. It is much, much lower than the balance of probability test applied in civil law claims.

The Supreme Court of Canada has characterised the essence of impartiality and bias as:

... the requirement of the judge to approach the case to be adjudicated with an open mind. Conversely, bias or prejudice has been defined as a leaning, inclination, bent or predisposition towards one side or another or a particular result. In its application to legal proceedings, it represents a predisposition to decide an issue or cause in a certain way, which does not leave the judicial mind perfectly open to conviction. Bias is a condition or 
state of mind, which sways judgment and renders a judicial officer unable to exercise his or her functions impartially in a particular case. ${ }^{84}$

The supreme importance to law's integrity of the requirement of judicial independence and impartiality is underlined in that it has a very low threshold - the mere apprehension of bias test. ${ }^{85}$ This suggests that the law's own integrity depends upon the absolute rejection of bias in its practice. Such integrity has nothing at all to do with the recognition or protection of the integrity of individuals that may be involved in the pursuit of justice.

Administrative law's doctrine of recusal of judges manifests inter alia the unreliability of pointing to judges' own integrity over law's own integrity. Judges often miss it that their personal circumstances are so linked to the facts of the case in a manner that triggers the apprehension of bias.

The test to be applied in determining whether a judge is disqualified by reason of the appearance of bias is whether a fair-minded lay observer might reasonably apprehend that the judge might not bring an impartial and unprejudiced mind to the resolution of the question the judge is required to determine. ${ }^{86}$

The High Court of Australia stated in Livesey v. New South Wales Bar Associa$t_{i o n}{ }^{87}$ that '... a fair-minded observer might entertain a reasonable apprehension of bias by reason of pre-judgment if a judge sits to hear a case at first instance after he has, in a previous case, expressed clear views either about a question of fact which constitutes a live and significant issue in the subsequent case or about the credit of a witness whose evidence is of significance on such a question of fact'. Justice Eder stated in Otkritie International Investment Management Ltd v. Urumov that '... cases in which there is any real ground for doubt should be resolved in favour of recusal. [However,] ...A judge should decline to hear a case only for proper and sufficient reason to do so: recusal is not an excuse for avoiding embarrassment'.88

84 Elizabeth Plomp v. Centre Hospitalier de St. Mary, Supreme Court of Canada, 2014 QCcs 6506.

85 See also Supreme Court of Canada decision 2747-3174 Québec Inc. v. Québec (Régie des permis d'alcool) [1996] 3 S.C.R. 919 .

86 Ninan v. Valuer General (WA) [No 2] [2016]WASCA 170 [20]; see also Johnson v. Johnson [2000], HCA 48, (2000) 201 CLR 488 [11].

87 Livesey v. New South Wales Bar Association (1983) 151 CLR 288, p. 300.

88 Otkritie International Investment Management Ltd v. Urumov, High Court of Justice, Queen's Bench Division Commercial Court, 29 April 20142014 WL 1219815. 
Despite the injunction that, in recusal matters, Judges should lean always '... on the side of being safe rather than sorry,', 89 judges are not unknown to refuse to recuse themselves, ${ }^{90}$ even when their own peers suggest it to them that the circumstances required it.

The reasonable apprehension of bias test has evolved to ensure impartial and independent hearings ${ }^{91}$ particularly in human rights cases involving the application of quasi-judicial powers by statutory bodies. ${ }^{92}$

The Supreme Court of Canada ${ }^{93}$ held that the reasonable apprehension of bias had been satisfied where employees of the Liquor Control Board which had power to revoke liquor licences had participated in every stage of the complaint process, including the investigation and the filing of complaints, the presentation of the case before the directors, and the making of the board's decision. The Court quashed the Board's decision for failure to comply with the requirement to ensure 'independent and impartial hearing' - contrary to human rights law. ${ }^{94}$

Section 23 of the Charter of Human Rights and Freedoms (Que.) provides that every person has the right to a hearing by an independent and impartial tribunal for the determination of his or her rights and obligations. Section $5^{6}(1)$ provides that a tribunal, for the purposes of Section 23, includes an agency exercising quasi-judicial functions. The guarantee to impartial, unbiased, independent consideration of matters alleged against anyone is not limited to courts and tribunals. Rather, its extension to agencies exercising quasi-judicial

$89 \quad A W G$ Group v. Morrison [2006] 1 WLR 1163, p. 9.

9o See also Otkritie International Investment Management Ltd v. Urumov, High Court of Justice, Queen's Bench Division Commercial Court, 29 April 2014 WL 1219815; JSC BTA Bank v. Ablyazov, Court of Appeal (Civil Division) 27 November 2012 [2012] WL 5894506.

91 See also Article 2(1) International Covenant on Civil and Political Rights, 16 December 1966, 999 UNTS 171.; Article 8(1) Organisation of American States, American Convention on Human Rights (22 November 1969); Article 6 European Convention on Human Rights (1950); ECHR 'Guide on Article 6 of the ECHR', ECHR website <http://www.echr.coe.int/ Documents/Guide_Art_6_ENG.pdf>; see also International Commission of Jurists, Practitioner's Guide No. 1 'International Principles on the Independence and Accountability of Judges, Lawyers and Prosecutors', www.refworld.org/pdfid/4a7837af2.pdf.

92 Human Rights Committee, General Comment No. 32, U.N. Doc. CCPR/C/GC/32 (2007), Article 14: Right to equality before courts and tribunals and to a fair trial.

93 2747-3174 Québec Inc. v. Québec (Régie des permis d'alcool) [1996] 3 S.C.R. 919.

94 Including the Charter of Human Rights and Freedoms, R.S.Q., c. C-12, ss. 23, 56(1)—Act respecting liquor permits, R.S.Q., c. P-9.1, ss. 2, 75, 86(8). 
functions reflects its paramountcy to fairness in all matters that affect fundamental rights of individuals.

The UN Human Rights Committee is comprised of 18 independent experts tasked with monitoring and enhancing State compliance with their obligations under the International Covenant on Civil and Political Rights (1966). ${ }^{95} \mathrm{Hu}-$ man Rights Committee General Comment No. 32 of 23 August 2007 simplifies for States the requirements that they must satisfy in order to ensure fairness in the practice of courts and tribunals as a means to safeguard the rule-of-law. It states that the equal treatment of parties applies regardless of the nature of proceedings before such bodies. 'Article 14 contains guarantees that States parties must respect, regardless of their legal traditions and their domestic law ... [and] ... a general reservation to the right to a fair trial would be incompatible with the object and purpose of the Covenant'. ${ }^{96}$

Paragraph 18 of the General Comment states that: "The notion of a "tribunal" in Article 14, paragraph 1 designates a body, regardless of its denomination, that is established by law, is independent of the executive and legislative branches of government or enjoys in specific cases judicial independence in deciding legal matters in proceedings that are judicial in nature. ${ }^{97}$

The International Commission of Jurists too has focused on this requirement and published an elaborate Practitioner's Guide on International Principles on the Independence and Accountability of Judges, Lawyers and Prosecutor. ${ }^{98}$ The reasonable apprehension of bias test has evolved in the jurisprudence on the prohibition against bias to ensure impartial and independent hearings particularly in human rights cases involving quasi-judicial statutory bodies.

The ICC fits all of the above descriptors. Its own integrity as a judicial tribunal depends also upon its demonstration that it adheres to the tenets of fair and impartial practice that can never be impugned in the slightest by accusations of apprehension of bias. However, the $6 \mathrm{July} 2017$ decision of Trial Chamber II in a matter against a MSP of the Rome Statute (1998) raises enormous doubt about the Court's recognition of the requirements of the nemojudex in parte sua principle of fairness and natural justice.

Firstly, the Court alleged that the Republic of South Africa had breached articles on cooperation by failing to honour ICC requests to arrest and surrender

Established under Articles 28 and 29 of the International Covenant on Civil and Political Rights, 16 December 1966, 999 UnTS 171.

96 Human Rights Committee, General Comment No. 32, Article 14: Right to equality before courts and tribunals and to a fair trial, U.N. Doc. CCPR/C/GC/32 (2007).

$97 \quad$ Ibid.

98 International Commission of Jurists, supra note 91. 
President Al Bashir during his visit of June 2015. The Court then presided over the proceedings. The Court reached the decision that indeed the Republic of South Africa had prevented it from doing its work by failing to arrest and surrender, as requested by itself, President Al Bashir while in the Republic of South Africa to attend an AU Summit.

This writer contends that these highly qualified and seasoned practitioners could not have been unaware of the apprehension of bias in what they were doing. Rather, survival instincts, similar to those observed in the early years of the ICJ ${ }^{99}$ must have overtaken their renowned wits and jointly focused them on politico-vivere-reflexes. They found immediate support for these instincts in woefully drafted Article 87 of the Rome Statute which must be amended to ensure that the Court's powers do not conflict with the general principle of judicial practice, namely, nemojudex in parte sua, itself a fundamental requirement of the principle of the rule of law. 100

This was not the First time that the ICC had considered the question of noncooperation with the Court by an African State and reached a similar decision. In December 2011, the ICC's Pre-Trial Chamber I considered violations by Chad and Malawi for failure in each case to cooperate with the ICC upon the Court's requests to arrest and surrender $\mathrm{Al}$ Bashir when he had visited their respective territories. ${ }^{101}$ Six years later, the ICC has repeated the same unconscionable procedure. This is a worrying development. The ICC cannot maintain this practice without undermining international criminal legal practice's very own integrity. If the ICC continues on this path, it might reduce itself to a body whose edicts are devoid of judicial credibility, confidence or legitimacy.

\section{$4 \quad$ Nemojudex in parte sua principle and the Case for Reform of Article 87(7)}

The duty to cooperate with the ICC is unequivocal. Article 86 provides that: 'States Parties shall, in accordance with the provisions of this Statute,

99 Corfu Channel (United Kingdom of Great Britain and Northern Ireland v. Albania), 9 April 1949, International Court of Justice, ICJ Reports 1949.

100 Human Rights Committee, General Comment No. 32 (23 August 2007) U.N. Doc. CCPR/ $\mathrm{C} / \mathrm{GC} / 32$, paras. 2 and 4.

101 The Prosecutor v. Omar Hassan Ahmad Al Bashir, 12 December 2011, ICC, Pre-Trial Chamber I, 02/05-01/og (Malawi non-compliance with ICC request for the arrest and surrender of President Al Bashir); The Prosecutor v. Omar Hassan Ahmad Al Bashir, 13 December 2011, ICC, Pre-Trial Chamber I, 02/05-01/o9 (Chad non-compliance with ICC request for the arrest and surrender of President Al Bashir). 
cooperate fully with the Court in its investigation and prosecution of crimes within the jurisdiction of the Court'. The imperative mood of the verb used suggests that the duty may be absolute, leaving MSPs no room for deliberation. If this is correct, MSP's failure to cooperate with the ICC upon request for assistance would be a serious breach of their obligations under the Rome Statute (1998) and under customary international law's pacta sunt servanda principle.

By Article 87, the plenipotentiaries sought to address the potential that MSPs might refuse as African States have done, to cooperate with the ICC. Subparagraph 7 of that Article provides that:

Where a State Party fails to comply with a request to cooperate by the Court contrary to the provisions of this Statute, thereby preventing the Court from exercising its functions and powers under this Statute, the Court may make a finding to that effect and refer the matter to the Assembly of States Parties or, where the Security Council referred the matter to the Court, to the Security Council.

The provision is based on, and driven by three assumptions. The first is that a State has failed to comply. Such circumstance would trigger the operation of $87(7)$. But the trigger requires a prior determination, namely, that a State has already defaulted. Neither the presumption of innocence nor, the possibility of extraneous circumstances is inscribed into this provision. It implies instead that the State always has at its disposal the unhindered power to cooperate. It implies also, the unequivocal supremacy of ICC law over MSPs.

The second bias-ridden trigger is that the ICC has to impute to the allegedly defaulting State its own failures. This is unconscionable because ICC arrest warrants against President Al Bashir for instance, have languished unenforced since 2009. For six years before the fugitive visited the Republic of South Africa, the Court had been unable to enforce those arrest warrants, and therefore not been able to prosecute President Al Bashir. According to the wording of Article 87(7) it suddenly becomes the Republic of South Africa in 2015, that has 'hindered the ICC from prosecuting the Sudanese President', and therefore responsible under international law for the Court's own six-year-long failure to bring its declared fugitive to book.

This raises an apprehension of unfair blame against the Republic of South Africa for international law's own weaknesses in that its ambition to prosecute those suspected of having incurred international criminal responsibility under its criminal code has not been matched yet by a corresponding boldness to achieve that ambition. Thus, it seeks to pass the blame onto States that find 
themselves in the Republic of South Africa's position, the responsibility for international law's own inherent weaknesses.

Consequently, these States are blamed for being in the quandary of having to balance the competing obligations arising from their supranational law obligations and also from their ICC obligations. The Court of Justice of the European Union prioritized supranational law over international law in the Kadi cases. ${ }^{102}$

Where the ICC has gone for six or more years without succeeding to bring an accused person to book, the blame should lie with the still weak and feeble nature of international law to achieve its ambitious programme ${ }^{103}$ to prosecute those alleged to have committed heinous crimes of concern to all of humanity. No matter how desirable and agreeable such a programme may be, without establishing a sufficient operational mechanism, its promises will remain illusory. Blaming the Republic of South Africa, which is mired up in contradicting supranational obligations which supposedly trump international law obligations per Kadi Case, appears to be childish nonsense. It does not deal with the challenge of the chasm between the ambition to prosecute Article 5 crimes of the Rome Statute (1998), and the lamentable absence of a sufficient mechanism to bring accused persons to the Court.

Pre-Trial Chamber II's 6 July 2017 decision against the Republic of South Africa appears to be a desperate attempt to fudge the current underdevelopment of international law, and the impotence of the ICC. This probability has opened up a can of worms for the ICC and non-cooperating AU MSPs that are also ICC MSPs are exploiting this malaise to defy the Court; leaving the reputation of the Court tainted.

The approach of the ICC in this case lends itself to criticism of exhibiting existentialist-vivere reflexes rather than the preferred sound judicial practice that inscribes General Principles of Law recognised by civilized nations Article 38(1)(c), Statute of the ICJ (1945). This writer does not imagine that the learned judges at the ICC are unaware of the apprehension of bias consequent upon a resort to exercising Article 87(7) powers against a MSP of the Rome Statute (1998). However, faced with challenges to its own legitimacy, Pre-Trial Chamber II - like Pre-Trial Chamber I before it in the Chad and Malawi cases of 2011 - chose to ignore application of the nemo judex in parte sua principle to the matters before it.

This raises two immediate issues. One is the defective drafting of Article $87(7)$ of the Rome Statute (1998). This provision should inscribe rather than

102 Supra section 2.3.

103 Flagging the challenges, see especially Jain, supra note 17, pp. 114-116. 
exclude operation of the requirements of nemo judex in parte sua. Secondly, it points to the enduring fault-line of deficient or poor enforcement mechanisms in international law. New challenges will demand resolute responses to both of these issues.

Enforcement of ICC arrest warrants should not be a burden for MSPs whose sentiment not to prosecute may be widely shared in their regional contexts. That only leads to the criminalization of MSPs for failing to accomplish something no single State can sometimes perform, particularly under the compelling rudiments of supranational law. To purposively interpret Article $87(7)$ as requiring MSPs to individually accomplish something that the international collective manifestly appears inept at accomplishing for itself is patently ridiculous.

UN Security Council in-action following Pre-Trial Chamber I's referrals of both Chad and Malawi's earlier non-cooperation with the ICC over President Al Bashir raises questions about the independence of a Court of law that pleads to political authority of the Executive for sanctions against non-cooperating States. It would be helpful to rid the Court of this dependence.

Often, political measures have a completely different set of checks and balances. What is acceptable in the political arena may be totally unacceptable in the judicial arena. Often, political instincts dictate and shape procedures in the political environment. However, consistency, transparency and predictability dictate and shape legal environments for dispute resolution. What is required is that international law should now cross bridges that it has hitherto hesitated to cross, particularly on the enforcement of international criminal law. Otherwise it is inconceivable that the ICC project will be very successful.

\section{5}

\section{Conclusions}

This article examined ICC practice on Article 87(7) of the Rome Statute, under the light of the nemo judex in parte sua principle. The discussion showed that justice is possible only when that practice follows the course of fairness by adhering to the strictures of the doctrine of natural justice. Natural justice refers to the functional element of law, which is to endear legal practice with integrity (faultlessness) and legitimacy (voluntary compliance of law's addressees). It has been summed up as the general duty to act fairly. Fairness in proceedings is ensured by two doctrines, namely, the rule against bias - nemo judex in parte sua; and the right to a fair hearing - audi alteram partem.

A tentative survey of domestic Courts' practice on the duty to act fairly (to determine general practice of States) showed extreme sensitivity to the 
strictures of the nemo judex in parte sua principle. Recognition of, and adherence to that principle made it overwhelmingly synonymous with a litmus test for justice in judicial proceedings. It also reinforces the human right to be tried by an independent and impartial tribunal. Nemo judex in parte sua is inextricable to the principle of the rule of law. It is a requirement championed by all human rights regimes.

The HRC, a body of experts that monitors State compliance with their obligations under the UN ICCPR (1966) has focused its work on this requirement and produced a coherent crystallization of its interpretation of this requirement in General Comment 32 on the interpretation of Article 14 on the right to fair trial. General Comments of the UN HRC are intended as authoritative guidance to States on the correct interpretation of treaty provisions.

According to the UN HRC the equal treatment of parties '... applies regardless of the nature of proceedings'. Moreover,

Article 14 contains guarantees that States parties must respect, regardless of their legal traditions and their domestic law .... [and] ... a general reservation to the right to a fair trial would be incompatible with the object and purpose of the Covenant. ${ }^{104}$

In three major cases - Chad, Malawi, and more recently the Republic of South Africa - Article 87(7) was invoked to charge each of these three States with non-cooperation with ICC requests for assistance to apprehend and surrender a fugitive. In each case the ICC found against the respondents and averred that by their conduct, each of the respondents had therefore prevented the Court from exercising its functions and powers under the Statute. The ICC's unquestioning implementation of Article 87(7) appears to contradict the nemo judex in parte sua requirement - itself a core principle of the requirement of natural justice, or the requirement to act fairly.

If this is correct, then Article 87(7) of the Rome Statute (1998) appears not to currently fully inscribe the requirements of natural justice, particularly the strictures of nemo judex in parte sua - a General Principle of Law recognized by civilized nations and recognized as a seminal source of Law under Article $38(1)$ (c) of the Statute of the ICJ, which has become customary law on the sources of international law. For this reason, perhaps a revision or, a redrafting of Article 87(7) of the Rome Statute (1998) is required to ensure that the provision inscribes the strictures of the nemo judex in parte sua principle. This

104 Supra note 92. 
would enhance the chances that ICC practice will be more consistent with the requirements of the nemo judex in parte sua principle.

That, both Pre-Trial Chamber I and Pre-Trial Chamber II have followed what appears under the light of natural justices' requirements as the flawed Article $87(7)$ logic, shows the Court's inclination towards politico-vivere-reflexes observed of the ICJ in its embryonic phase, particularly its decision in the Corfu Channel case (1949). If as we have seen above, impartiality is the core attribute of judicial proceedings, ${ }^{105}$ then the ICC could not insist on exercising the flawed logic of Article 87(7) without offending the common notions of justice.

These peculiar circumstances highlight a very critical moment in the development of international law generally, and of international criminal law in particular. In the first eight years of its existence the ICC did not bring a single accused person to trial in spite of several indictments. This points in part to the underdevelopment of the international legal system. It cannot yet match with a fitting process, its justifiable ambition to prosecute those alleged to have committed heinous crimes of concern to all of humanity. The Al Bashir case before the ICC shows severe weaknesses in the ICC dynamic to achieve its mission. No matter how desirable and agreeable the ICc project may be, without providing a sufficient operational dynamic for its functions, its promises will remain pie in the sky and illusory.

Finally, two things need addressing. One is the defective drafting of Article $87(7)$ so that it inscribes the requirements of the nemo judex in parte sua principle. The second is to deal with international law's enduring fault-line, namely, enforcement strategies. This fault-line can no longer subsist. Enforcement of ICC arrest warrants should not remain a burden for MSPs. The Al Bashir case has proven this to be an extremely unreliable Walter Mitty ${ }^{106}$ approach to prosecution of international crimes. To purposively interpret Article 87(7) as requiring MSPs to individually accomplish that, which the international collective appears inept to accomplish, is perplexing and a recipe for failure of the ICC project.

105 Canadian Judicial Council, supra note 1, pp. 30.

106 See James Thurber, The Secret Life of Walter Mitty (Penguin, London, 1945). 